\title{
Brown Marmorated Stink Bug (Halyomorpha halys Stål.) Attack Induces a Metabolic Response in Strawberry (Fragaria $\times$ ananassa Duch.) Fruit
}

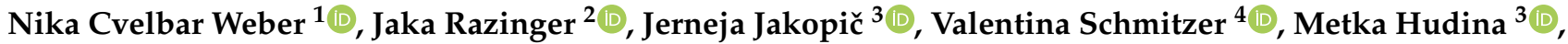 \\ Ana Slatnar ${ }^{3}$, Robert Veberič ${ }^{3}$ D , Franci Štampar ${ }^{3}$ and Tilen Zamljen ${ }^{3, * D}$
}

1 Department of Fruit Growing, Viticulture and Oenology, Agricultural Institute of Slovenia, Hacquetova ulica 17, SI-1000 Ljubljana, Slovenia; nika.weber@kis.si

2 Plant Protection Department, Agricultural Institute of Slovenia, Hacquetova ulica 17, SI-1000 Ljubljana, Slovenia; jaka.razinger@kis.si

3 Department of Agronomy, Biotechnical Faculty, University of Ljubljana, Jamnikarjeva 101, SI-1000 Ljubljana, Slovenia; jerneja.jakopic@bf.uni-lj.si (J.J.); metka.hudina@bf.uni-lj.si (M.H.); ana.slatnar@bf.uni-lj.si (A.S.); robert.veberic@bf.uni-lj.si (R.V.); franci.stampar@bf.uni-lj.si (F.Š.)

4 Department of Landscape Architecture, Biotechnical Faculty, University of Ljubljana, Jamnikarjeva 101, SI-1000 Ljubljana, Slovenia; valentina.schmitzer@bf.uni-lj.si

* Correspondence: tilen.zamljen@bf.uni-lj.si; Tel.: +386-40-240-201

Citation: Weber, N.C.; Razinger, J.; Jakopič, J.; Schmitzer, V.; Hudina, M.; Slatnar, A.; Veberič, R.; Štampar, F.; Zamljen, T. Brown Marmorated Stink Bug (Halyomorpha halys Stål.) Attack Induces a Metabolic Response in Strawberry (Fragaria $\times$ ananassa Duch.) Fruit. Horticulturae 2021, 7, 561. https://doi.org/ 10.3390/horticulturae7120561

Academic Editor: Christopher M. Menzel

Received: 9 November 2021 Accepted: 6 December 2021 Published: 8 December 2021

Publisher's Note: MDPI stays neutral with regard to jurisdictional claims in published maps and institutional affiliations.

Copyright: (c) 2021 by the authors. Licensee MDPI, Basel, Switzerland. This article is an open access article distributed under the terms and conditions of the Creative Commons Attribution (CC BY) license (https:// creativecommons.org/licenses/by/ $4.0 /)$.

\begin{abstract}
The polyphagous brown marmorated stink bug (Halyomorpha halys Stål.) is an important pest in many countries. Recently it was noticed that it can feed on and cause damage to strawberries (Fragaria $\times$ ananassa Duch.). The metabolic response of strawberries to brown marmorated stink bug attacks was studied. Brown marmorated stink bugs attacked strawberry fruit which had $18 \%$ lower total sugar content compared to that of the control treatment. However, organic acid content had no significant difference among the three treatments, with the exception of shikimic acid, which had the highest content in the attacked fruit. Thirty-one phenolic compounds were identified. Results showed a strong effect on secondary metabolites due to $H$. halys attacks. Halyomorpha halys treatment had $27 \%$ higher total analyzed phenolic content compared to the indirect Halyomorpha halys treatment. The brown marmorated stink bug significantly increased total ellagic acid derivatives (33.1\% to $37 \%$ higher), hydroxycinnamic acids (22.3\% higher) and anthocyanins' (39\% higher) contents. Fruit attacked by Halyomorpha halys also had higher catechin and epicatechin content than that of the control treatments. This pest had a significant influence on the plant's secondary metabolism, and this improved our understanding of how a strawberry plant reacts to the attacks of this very important pest. H. halys-infested fruit are not suitable for commercial production, due to the production of off-flavors.
\end{abstract}

Keywords: anthocyanins; ellagic acid derivatives; hydroxycinnamic acids; strawberry; total sugars; total organic acids

\section{Introduction}

The brown marmorated stink bug Halyomorpha halys Stål. (Hemiptera: Pentatomidae) has started to spread across Slovenia since 2017 in a similar pattern to other European countries [1]. H. halys originates from China, Japan, Korea and Taiwan, but has now rapidly spread to North America and Europe due to several reasons, of which the main ones are climate change and a lack of natural predators [2]. The damage is significant especially in apple, pear, peach or cherry orchards, with yield losses of up to $50 \%$ or more $[3,4]$. It can also cause the decrease in yield and of its quality after storage, as previously reported by Zamljen et al. [5]. Recently, farmers have also reported damage to strawberries (Fragaria $\times$ ananassa Duch.). Halyomorpha halys feeds on the fruit, causing small puncture wounds which tend to rot in storage rooms, causing significant losses to 
marketable yields [6-8]. H. halys is recognized by white and black banding on the antennae and abdominal margins. White eggs are laid on the underside of leaves in clusters. The eggs (up to 28 per cluster) can be laid by the female every four days throughout its life span as an adult. In Europe, there are two generations of $H$. halys per year. Nymphs hatch approximately 4 to 7 days after the eggs are laid. The five nymphal stages from hatching to adulthood take from 33 to 55 days. The males are smaller than the females and have a rear ventral scoop [9]. Controlling $H$. halys populations in orchards is difficult due to several reasons, the first being the lack of appropriate plant protection substances registered [10] for $H$. halys, and the second being the great variety of host plants (over 100) that the bug feeds on [11]. A strawberry attacked by H. halys is darker and swollen-looking. It also has a noticeable smell which is common for a stink bug attack. The attacked fruit does not last long in storage rooms and starts to mold and rot. Strawberries attacked by H. halys are also not suitable for juice, since the taste and smell remain even after processing [12].

In strawberries and other plants, the natural reaction to any pests or disease attacks is the production of phenolic compounds, which act as a repellent or are toxic to certain pests and diseases [13]. Common phenolic groups in strawberries are hydroxycinnamic acids, ellagic acid derivatives, flavanols, flavonols and anthocyanins. Ellagic acid derivatives are known defensive metabolites; their tissue concentrations increase when a plant is attacked by a pest or disease [7].

Phenolics can inhibit insect oviposition, feeding, growth and development at different stages. Tannins in insects reduce growth and act as enzyme inactivators. Some phenolics can also influence insects' reproduction periods [14]. Phenolics can be directly toxic to the insect or are used as a signaling molecule which activates the synthesis of other toxic secondary metabolites [15]. There are relatively few reports in literature about pests' attacks and subsequent plants' responses in terms of metabolites.

For the first time ever, we noted and analyzed a metabolic response of strawberries when attacked by Halyomorpha halys. Halyomorpha halys' damage to strawberries had previously not been analyzed and reported in a detailed manner. In additon to individual sugars and organic acids, we also studied the response of 31 individual phenolic compounds, explaining how a strawberry fruit reacts to Halyomorpha halys attacks on a metabolic scale. This study gives a great insight to how the quality of the fruit changes in regard to Halyomorpha halys damage. The results of this study improve our understanding of the significance of controlling the brown marmorated stink bug population in orchards and other plant production fields to reduce the damage to crops and agriculture.

\section{Materials and Methods}

\subsection{Plant Material and Growing Conditions}

Strawberries in our experiment were grown according to the integrated production guidelines of the Ministry of Agriculture, Forestry and Food at the experimental station of the Agricultural Institute of Slovenia, located in Brdo pri Lukovici (latitude, $46^{\circ} 10^{\prime} \mathrm{N}$; longitude, $14^{\circ} 41^{\prime} \mathrm{E}$ ). The field trial was carried out on silty loam soil, rich in potassium and nitrogen and low in phosphorus, equipped with a drip irrigation system. Frigo strawberry plants (Fragaria $\times$ ananassa Duch.) cv. Clery were planted in an open field on 15 August, 2019 , on slightly raised beds covered with black polyethylene, then covered in a non-heated plastic greenhouse on 3 April, 2020. Plants were planted in double rows, with $0.25 \times 0.25 \mathrm{~m}$ spacing between the plants and $1.3 \mathrm{~m}$ spacing between the rows or raised beds. For the experiment, we selected uniform strawberry plants that had 3 stems forming a crown. The strawberries in this experiment were grown in a very controlled manner (use of insect nets and pesticides if needed) so that no diseases or pests (other than $H$. halys) could affect the results.

An experiment was conducted to evaluate the effect of Halyomorpha halys (Stål) on strawberry fruit. Three treatments were carried out: (i) control treatment (healthy plants without pests); (ii) $H$. halys treatment, in which two flower stems per plant bearing ripening fruit were covered with a soft nylon plastic insect bag measuring $\mathrm{L} 30 \times \mathrm{W} 10 \mathrm{~cm}$ and net 
measuring $104 \times 94$ mesh/square inch (BugDorm, Taichung City, Taiwan), infested with two second stage $H$. halys nymphs, which were caught by pheromone traps, as previously reported by Short et al. [16] and sealed with strings; (iii) indirect Halyomorpha halys treatment, in which healthy uninfested fruit were collected from the same plant infested with $H$. halys. The $H$. halys nymphs were examined once a week and all dead specimens were replaced with healthy ones to ensure constant infestation (This was conducted for four weeks). Each treatment was carried out on ten (10) plants; a total of 20 plants were included (10 plants for control treatment, 10 plants with $H$. halys treatment and indirect $H$. halys treatment). Fruit samples for biochemical analyses were collected at the fifth harvest on June 5. Each treatment was represented with five repetitions, each repetition consisting of five fruits, to reduce any difference in ripeness among fruit from the same treatment. Ripe fruits were picked early in the morning when temperatures did not exceed $15{ }^{\circ} \mathrm{C}$, labeled, immediately snap-frozen in liquid nitrogen, stored in plastic bags, transferred to the laboratory in liquid nitrogen and stored at $-20{ }^{\circ} \mathrm{C}$ for further analyses. For all metabolite extractions, fresh samples were first thawed at room temperature and blended in a blender while still cold to form a paste. This paste was then used for the extraction of the individual metabolites.

\subsection{Extraction of Sugars and Organic Acids}

One gram of fresh samples were extracted with $5 \mathrm{~mL}$ of bidistilled water for the extraction of sugars and organic acids. Samples were then shaken for $30 \mathrm{~min}$ and filtered through a $25 \mu \mathrm{m}$ cellulose filter (Chromafil A-25/25; Macherey-Nagel, Düren, Germany). Thermo Finnigan Surveyor HPLC system (Thermo Scientific, San Jose, CA, USA) was used for analyses. The column, settings and detection parameters were based on Zamljen et al. [17] and Weber et al. [18]. Relevant standards were used to calculate all data and all data were expressed in $\mathrm{g} / \mathrm{kg}$ FW (fresh weight).

\subsection{Extraction of Phenolics}

Three grams of fresh fruit samples and $10 \mathrm{~mL}$ of $80 \%$ methanol and $3 \%$ formic acid were used for the extraction of phenolic compounds. The samples were placed in an ultrasonic bath $\left(0^{\circ} \mathrm{C}\right)$ for $1 \mathrm{~h}$. After the ultrasonic bath, the samples were filtered through a $25 \mu \mathrm{m}$ polyamide filter (Chromafil AO-45/25, Macherey-Nagel, Düren, Germany). Identification of individual phenols was performed by tandem mass spectrometry (MS/MS; LTQ XL; Thermo Scientific, Waltham, MA, USA) with heated electrospray ionization in negative ion mode. The settings were the same as previously reported by Medic et al. [19]. Quantification of individual phenols was performed using a UHPLC system (Vanquish; Thermo Scientific, Waltham, MA, USA). The UHPLC system settings and column were the same as previously reported by Weber et al. [18]. Chromatographic information $(\mathrm{m} / \mathrm{z})$ for the identification of each individual phenolic are presented in Supplementals Tables S1-S3. The identification was based on references [18,20-27]. In Supplementals Figures S1-S3 we also present the chromatographic information for each wavelength. All ellagic acid derivatives were expressed as ellagic acid equivalents; procyanidin dimer 2 and procyanidin trimer were expressed as procyanidin B1 equivalents; all glucoside of kaempferol were expressed as kaempferol-3-glucoside equivalents; $p$-coumaroylhexosides and $p$ coumaroylhexose were expressed as $p$-cumaric acid equivalents; all caffetic acid derivatives were expressed as caffeic acid equivalents; all cinnamic acid derivatives and ferulic acid derivatives were expressed as equivalents of cinnamic acid and ferulic acid, respectively. Pelargonidin-3-malonylglucoside and pelargonidin-3-rutinoside were expressed as pelargonidin-3-glucoside. The total analyzed ellagic acid derivatives, flavanols, hydroxycinnamic acids and anthocyanins were a summarization of individual pheonlics in each appropriate group. All data were expressed in $\mathrm{mg} / \mathrm{kg} \mathrm{FW.}$ 


\subsection{Chemicals}

The following standards were used to determine the chemical compounds: apigenin 7-glucoside, kaempferol-3-glucoside, procyanidin B1, quercetin-3-glucoside, quercetin-3rhamnoside, ferulic acid, $p$-coumaric acid from Fluka Chemie GmbH (Buchs, Switzerland), (+)-catechin from Roth (Karlsruhe, Germany), 4-caffeoylquinic acid, chlorogenic acid (trans-5-caffeoylquinic acid), neochlorogenic acid (3-caffeoylquinic acid), quercetin-3galactoside, quercetin-3-rhamnoside, caffeic acid, galic acid, (-)-epicatechin from SigmaAldrich Chemie GmbH (Steinheim, Germany), myricetin-3-rhamnoside, quercetin-3arabinofuranoside, quercetin-3-arabinopyranoside, quercetin-3-xyloside from Apin Chemicals (Abingdon, UK).

For sugars, standards for glucose, sucrose and fructose were used from Sigma-Aldrich Chemie GmbH (Steinheim, Germany) and for organic acids, standards of citric acid, malic acid, shikimic acid and fumaric acid were used from Sigma-Aldrich Chemie GmbH (Steinheim, Germany).

\subsection{Statistical Analysis}

Data were statistically processed using R program (Team, 2008). For all data, mean and standard error were calculated. Significant treatment effects were found using analysis of variance (ANOVA) and the LSD test. The significant level was $\alpha \leq 0.05$. Where differences were observed, lowercase letters $(a, b)$, were added to distinguish between which treatment they were present for or not.

\section{Results and Discussion}

\subsection{Visual Appearance of Strawberry}

The color of the H. halys-infested strawberry was dark red, and the tissue was swollenlooking (Figure 1). The fruit was also characterized by a distinct odor, caused by the stink bug and associated with two defense chemicals, namely trans-2-octenal and trans-2-decenal aldehydes [28]. Strawberries with this scent cannot be sold to consumers.

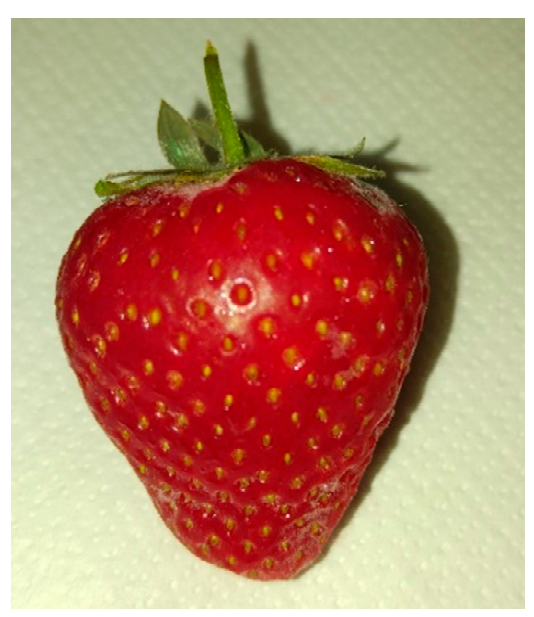

(A)

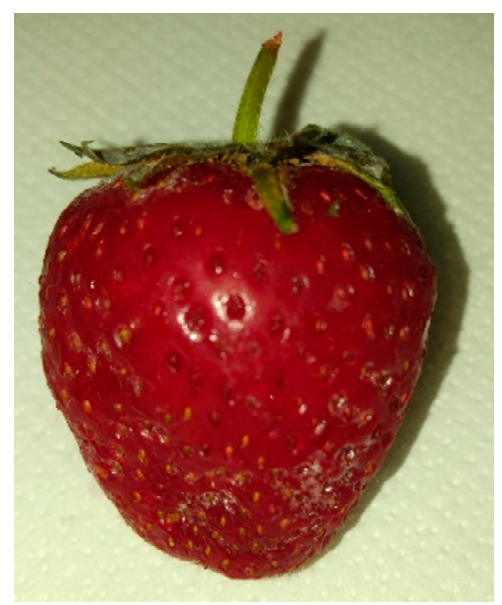

(B)

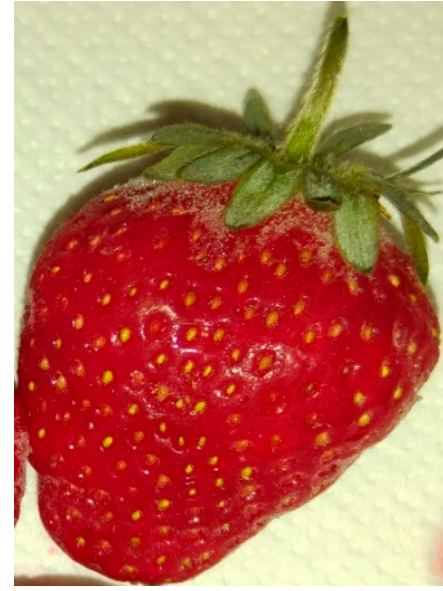

(C)

Figure 1. Control strawberry (A); H. halys-infested strawberry (B); and indirectly H. halys-infested strawberry (C).

\subsection{Sugars}

Three individual sugars were determined in strawberry fruit (Table 1). The content of all three individual sugars (sucrose, glucose and fructose) was highest in the control treatment, with glucose and fructose being the most abundant in all three treatments. Halyomorpha halys treatment was characterized by the lowest content of all three sugars. The control treatment had $41.1 \%$ higher sucrose content, $14.6 \%$ higher glucose content and $10.5 \%$ higher fructose content compared to the Halyomorpha halys-infested strawberry. 
Consequently, the control treatment had $14.3 \%$ and $18 \%$ higher total sugar content compared to the indirectly Halyomorpha halys-infested fruit and the Halyomorpha halys treatment, respectively. Strawberries of the control treatment had similar sugar content, as previously reported by Milivojević et al. [29]. Our results were similar to those of Wiman et al. [6], Zhou et al. [12] and Schumm et al. [2] which reported decreased sugar content following Halyomorpha halys attacks on blueberries and tart cherries. A possible reason for the decrease in sugars can be ascribed to preference in sugar consumption of Halyomorpha halys, since it mostly feeds on fruit juices and sugars that are present in them. The second reason for the lower sugar content may also be related to higher phenolic content, since they are synthesized as defense compounds. Glucose is used as the main substrate for the synthesis of phenolics, which would explain the lower sugar content and higher phenolic content, as previously reported by War et al. [14] and Kaur et al. [15].

Table 1. Individual and total sugar content ( $\mathrm{g} / \mathrm{kg} \mathrm{FW}$, mean $\pm \mathrm{SE})$ in strawberry fruit.

\begin{tabular}{ccccccc}
\hline & \multicolumn{2}{c}{ Control } & & \multicolumn{2}{c}{ Halyomorpha halys } & \multicolumn{2}{c}{ Indirect Halyomorpha halys } \\
\hline Sucrose & $10.20 \pm 0.41$ & $\mathrm{a}^{*}$ & $6.01 \pm 0.62$ & $\mathrm{~b}$ & $6.62 \pm 0.44$ & $\mathrm{~b}$ \\
Glucose & $21.82 \pm 0.40$ & $\mathrm{a}$ & $18.63 \pm 0.83$ & $\mathrm{~b}$ & $19.61 \pm 0.42$ & $\mathrm{~b}$ \\
Fructose & $21.91 \pm 0.45$ & $\mathrm{a}$ & $19.62 \pm 0.76$ & $\mathrm{~b}$ & $20.02 \pm 0.35$ & $\mathrm{~b}$ \\
Total sugars & $53.93 \pm 0.52$ & $\mathrm{a}$ & $44.26 \pm 0.56$ & $\mathrm{~b}$ & $46.25 \pm 0.44$ & $\mathrm{~b}$ \\
\hline
\end{tabular}

* a,b lower case letters denote statistically significant differences $(\alpha<0.05)$ among different treatments.

\subsection{Organic Acids}

Four organic acids were quantified in strawberries (Table 2). No significant differences were detected for citric, malic and fumaric acid content. The Halyomorpha halys treatment positively affected the shikimic acid content compared to the indirect Halyomorpha halys treatment. No significant differences were determined in total organic acid content in all three treatments. Similarly, decreased organic acid content was previously determined in Colletotrichum nymphaeae-infected strawberries by Weber et al. [13]. No reports on the influence of Halyomorpha halys on organic acid content have been reported in past studies. Certain organic acids such as shikimic acid have an important role in phenolics synthesis [30]. The significant increase in shikimic acid in fruit attacked by Halyomorpha halys could be linked to the increased synthesis of phenolic compounds.

Table 2. Individual and total organic acid content $(\mathrm{g} / \mathrm{kg}$ FW, mean $\pm \mathrm{SE})$ in strawberry fruit.

\begin{tabular}{ccccccc}
\hline & \multicolumn{2}{c}{ Control } & & \multicolumn{2}{c}{ Halyomorpha halys } & \multicolumn{2}{c}{ Indirect Halyomorpha halys } \\
\hline Citric acid & $8.15 \pm 0.92$ & $\mathrm{a} *$ & $6.85 \pm 0.32$ & $\mathrm{a}$ & $6.23 \pm 0.27$ & $\mathrm{a}$ \\
Malic acid & $3.86 \pm 0.35$ & $\mathrm{a}$ & $3.95 \pm 0.24$ & $\mathrm{a}$ & $3.23 \pm 0.22$ & $\mathrm{a}$ \\
Shikimic acid & $0.05 \pm 0.01$ & $\mathrm{ab}$ & $0.06 \pm 0.00$ & $\mathrm{a}$ & $0.04 \pm 0.00$ & $\mathrm{~b}$ \\
Fumaric acid & $0.02 \pm 0.00$ & $\mathrm{a}$ & $0.02 \pm 0.00$ & $\mathrm{a}$ & $0.02 \pm 0.00$ & $\mathrm{a}$ \\
Total organic acid & $12.08 \pm 1.4$ & $\mathrm{a}$ & $10.88 \pm 1.8$ & $\mathrm{a}$ & $9.52 \pm 0.7$ & $\mathrm{a}$ \\
\hline
\end{tabular}

* a,b lower case letters denote statistically significant differences $(\alpha<0.05)$ among different treatments.

\subsection{Phenolics}

Seven phenolics groups and thirty-one individual phenolic compounds were identified in strawberry fruit (Table 3). Fruits infested with Halyomorpha halys contained higher levels of total ellagic acid derivatives, hydroxycinnamic acids and anthocyanins compared to all control treatments. Bis-HHDP-hexose was the most common phenolic compound among total ellagic acid derivatives, procyanidin dimer 1 and 2 among flavanols, kaempferol-3glucoside among flavonols, cinnamic acid hexoside among hydroxycinnamic acids and pelargonidin-3-glucoside and pelargonidin-3-rutinoside among anthocyanins. The total ellagic acid derivative content was $33.1 \%$ and $37 \%$ higher in Halyomorpha halys treatment compared to the control and indirect Halyomorpha halys treatment, respectively. The control fruit was characterized by $22.3 \%$ less hydroxycinnamic acid compared to strawberries infested with Halyomorpha halys. Moreover, the control fruit contained $400.12 \mathrm{mg} / \mathrm{kg}$ FW, and indirectly Halyomorpha halys-infested strawberries contained $357.46 \mathrm{mg} / \mathrm{kg}$ FW 
fewer anthocyanins compared to the Halyomorpha halys treatment. The control and indirect $H$. halys strawberries had $27 \%$ and $28 \%$ fewer total analyzed phenolics compared to fruit infested by brown marmorated stinkbugs. Similar phenolic content as our control treatment was also reported by Weber et al. [31].

Table 3. Individual and total phenolic content (mg/kg FW, mean $\pm \mathrm{SE})$ in strawberry fruit.

\begin{tabular}{|c|c|c|c|c|c|c|}
\hline \multirow[b]{2}{*}{ Total elgaic acid derivatives } & \multicolumn{2}{|c|}{ Control } & \multicolumn{2}{|c|}{ Halyomorpha halys } & \multicolumn{2}{|c|}{ Indirect Halyomorpha halys } \\
\hline & $326.0 \pm 12.0$ & $\mathbf{b}^{*}$ & $487.8 \pm 26.2$ & $\mathbf{a}$ & $307.6 \pm 21.8$ & $\mathbf{b}$ \\
\hline bis-HHDP-glucose & $85.0 \pm 4.7$ & $\mathrm{~b}$ & $132.3 \pm 10.3$ & a & $71.0 \pm 3.2$ & $\mathrm{~b}$ \\
\hline bis-HHDP-hexose & $154.0 \pm 11.4$ & $b$ & $222.3 \pm 24.8$ & $\mathrm{a}$ & $152.6 \pm 17.8$ & $\mathrm{~b}$ \\
\hline ellagic acid deoxyhexoside & $11.0 \pm 0.5$ & $\mathrm{~b}$ & $15.9 \pm 0.9$ & $\mathrm{a}$ & $13.2 \pm 1.2$ & $\mathrm{ab}$ \\
\hline Flavanols & $398.1 \pm 13.5$ & $\mathbf{a}$ & $436.4 \pm 29.2$ & $\mathbf{a}$ & $375.2 \pm 16.8$ & $\mathbf{a}$ \\
\hline procyanidin dimer 1 & $115.5 \pm 8.6$ & a & $149.7 \pm 3.6$ & $\mathrm{a}$ & $137.1 \pm 10.6$ & $\mathrm{a}$ \\
\hline procyanidin dimer 2 & $137.0 \pm 7.6$ & a & $124.8 \pm 6.8$ & $\mathrm{ab}$ & $104.9 \pm 8.0$ & $\mathrm{~b}$ \\
\hline procyanidin trimer & $78.5 \pm 2.9$ & a & $78.5 \pm 7.4$ & $\mathrm{a}$ & $79.5 \pm 8.1$ & $\mathrm{a}$ \\
\hline propelargonidin dimer & $12.1 \pm 1.4$ & a & $10.5 \pm 3.1$ & a & $10.2 \pm 2.6$ & $\mathrm{a}$ \\
\hline epicatechin & $38.6 \pm 4.5$ & $\mathrm{~b}$ & $52.9 \pm 12.5$ & a & $29.7 \pm 5.3$ & $\mathrm{~b}$ \\
\hline catechin & $16.4 \pm 0.8$ & $\mathrm{ab}$ & $19.6 \pm 0.4$ & a & $13.5 \pm 2.0$ & $\mathrm{~b}$ \\
\hline \multicolumn{7}{|l|}{ Flavone } \\
\hline apigenin rhamnoside & $1.10 \pm 0.1$ & a & $1.0 \pm 0.0$ & $\mathrm{a}$ & $0.9 \pm 0.1$ & $\mathrm{a}$ \\
\hline Flavonols & $21.7 \pm 1.2$ & $\mathbf{a}$ & $20.4 \pm 1.4$ & $\mathbf{a b}$ & $15.7 \pm 1.9$ & $\mathbf{b}$ \\
\hline kaempferol-3-coumaroyl glucoside & $0.2 \pm 0.0$ & a & $0.1 \pm 0.0$ & $\mathrm{a}$ & $0.2 \pm 0.0$ & $\mathrm{a}$ \\
\hline quercetin-3-glucuronide & $0.5 \pm 0.1$ & a & $0.3 \pm 0.0$ & a & $0.4 \pm 0.1$ & $\mathrm{a}$ \\
\hline kaempferol-3-glucoside & $12.2 \pm 0.7$ & a & $9.4 \pm 1.0$ & $\mathrm{ab}$ & $7.4 \pm 1.0$ & $\mathrm{~b}$ \\
\hline quercetin-3-malonyl glucoside & $1.3 \pm 0.1$ & $b$ & $1.9 \pm 0.1$ & a & $1.1 \pm 0.1$ & $\mathrm{~b}$ \\
\hline kaempferol-3-glucuoronide & $4.7 \pm 0.3$ & a & $4.6 \pm 0.2$ & a & $4.1 \pm 0.5$ & $\mathrm{a}$ \\
\hline isorhamnetin-3-glucuronide & $0.7 \pm 0.1$ & a & $0.2 \pm 0.1$ & $\mathrm{~b}$ & $0.3 \pm 0.1$ & $\mathrm{~b}$ \\
\hline kaempferol-3-acetyl glucoside & $2.3 \pm 0.1$ & $b$ & $3.5 \pm 0.1$ & $\mathrm{a}$ & $2.2 \pm 0.1$ & $\mathrm{~b}$ \\
\hline Hydroxycinnamic acids & $310.1 \pm 3.9$ & $\mathbf{b}$ & $401.7 \pm 5.4$ & a & $354.1 \pm 11.9$ & $\mathbf{a b}$ \\
\hline p-cumaroyl hexoside 1 & $12.6 \pm 0.3$ & $\mathrm{ab}$ & $14.3 \pm 0.6$ & a & $11.4 \pm 0.5$ & $\mathrm{~b}$ \\
\hline p-cumaroyl hexoside 2 & $3.4 \pm 0.1$ & a & $2.8 \pm 0.4$ & a & $1.4 \pm 0.2$ & $\mathrm{~b}$ \\
\hline p-cumaroyl hexoside 3 & $3.2 \pm 0.3$ & a & $3.6 \pm 0.5$ & $\mathrm{a}$ & $2.5 \pm 0.5$ & $\mathrm{a}$ \\
\hline cinnamic acid hexoside & $190.4 \pm 2.3$ & a & $182.7 \pm 4.1$ & $\mathrm{ab}$ & $163.1 \pm 10.7$ & $\mathrm{~b}$ \\
\hline caffeoylhexose & $0.9 \pm 0.0$ & a & $0.9 \pm 0.0$ & a & $0.6 \pm 0.1$ & $\mathrm{~b}$ \\
\hline caffeic acid derivate & $0.5 \pm 0.1$ & $b$ & $1.3 \pm 0.0$ & $\mathrm{a}$ & $0.5 \pm 0.1$ & $\mathrm{~b}$ \\
\hline ferulic acid hexose derivate & $87.0 \pm 2.2$ & $b$ & $133.1 \pm 5.7$ & a & $83.9 \pm 3.0$ & $\mathrm{~b}$ \\
\hline p-coumaroylhexose & $4.4 \pm 0.1$ & $\mathrm{~b}$ & $5.2 \pm 0.1$ & $\mathrm{a}$ & $4.1 \pm 1.1$ & $\mathrm{~b}$ \\
\hline cinnamic acid-3 acetylhexoside & $4.3 \pm 0.3$ & $\mathrm{a}$ & $3.52 \pm 0.20$ & a & $3.5 \pm 0.4$ & $\mathrm{a}$ \\
\hline \multicolumn{7}{|l|}{ Hydroxybenzoic acids } \\
\hline ellagic acid & $4.2 \pm 0.8$ & a & $4.87 \pm 0.46$ & a & $2.9 \pm 0.1$ & $\mathrm{a}$ \\
\hline Anthocyanins & $640.8 \pm 18.9$ & $\mathbf{b}$ & $1040.95 \pm 48.07$ & $\mathbf{a}$ & $683.5 \pm 38.9$ & $\mathbf{b}$ \\
\hline Cyanidin-3-glucoside & $38.8 \pm 0.6$ & $\mathrm{~b}$ & $57.98 \pm 3.79$ & a & $36.3 \pm 5.4$ & $\mathrm{~b}$ \\
\hline Pelargonidin-3-glucoside & $413.4 \pm 15.1$ & $\mathrm{~b}$ & $672.37 \pm 34.84$ & $\mathrm{a}$ & $420.7 \pm 20.4$ & $\mathrm{~b}$ \\
\hline Pelargonidin-3-malonylglucoside & $14.4 \pm 0.7$ & $\mathrm{~b}$ & $21.23 \pm 1.77$ & a & $18.3 \pm 1.1$ & $\mathrm{~b}$ \\
\hline Pelargonidin-3-rutinoside & $174.3 \pm 4.5$ & $\mathrm{~b}$ & $289.59 \pm 11.14$ & a & $208.4 \pm 16.7$ & $a b$ \\
\hline Total analyzed phenolics & $1625.2 \pm 28.5$ & $\mathbf{b}$ & $2226.64 \pm 58.60$ & $\mathbf{a}$ & $1589.6 \pm 53.0$ & $\mathbf{b}$ \\
\hline
\end{tabular}

* a,b lower case letters denote statistically significant differences $(\alpha<0.05)$ among different treatments.

A significant increase in total ellagic derivatives, hydroxycinnamic acids and anthocyanins was previously reported by Weber et al. [13] who studied Colletotrichum nymphaeaeinfected strawberry fruit. An increase in phenolics was also reported by Young et al. [32] in pak choi (Brassica rapa subsp. chinensis) infested with flea beetles (Altica spp.). Halyomorpha halys-infested blueberry fruit contained higher phenolic levels compared to non-infested fruit, as previously reported by Zhou et al. [12] which corresponds with our results. Catechin and epicatechin levels also increased in brown marmorated stink bug-infested strawberries, which corresponds with the antimicrobial, antifungal and insect repellent functions of these compounds, as reported by Veluri et al. [33] and Ullah et al. [34].

The Halyomorpha halys-infested strawberries' reaction is to increase the synthesis of phenolic compounds. This is a common response, since phenolics are known for their defensive role in plants [14,15]. Phenolics can act as repellents, disturbers or even toxins for insects. With the increased synthesis of certain phenolics, plants such as strawberries try to prevent the insect from feeding on the fruit. Increasing anthocyanin synthesis in Halyomorpha halys-infested strawberry could be a method of repelling or confusing the 
insect. Anthocyanins act as attractors for pollinators, as visual repellents for pests or for camouflage [35]. Anthocyanins also act as defensive molecules against fungal disease, as previously reported in grapes infected with Botrytis cinerea, reducing the infection by $95 \%$ as reported by Schaefer et al. [36]. The hazel's (Corylus avellana L.) caffeic acid content is higher in Myzocallis coryli Goetze (filbert aphid)-resistant cultivars, which demonstrates that caffeic acid is synthesized in the plant for the purpose of defense against sucking and piercing insects, as previously reported by Gantner et al. [37]. Similarly, an increase in caffeic acid content was also detected in our study.

\section{Conclusions}

The brown marmorated stink bug (Halyomorpha halys Stål.) is an invasive pest in Europe, America and Asia. Because of its wide host range, it is difficult to keep it from spreading. This study has shown that it can also target strawberry plants. A natural defense mechanism of strawberry fruit is the synthesis of different metabolites, which can repel, confuse or be toxic to the attacker. Our study is a detailed report on the metabolic response of strawberries to brown marmorated stink bug (Halyomorpha halys Stål.) attacks. The attacked fruit had 18\% lower sugar content and a higher total analyzed phenolics content compared to the control treatment. The main phenolics that increased in the attacked fruit were total ellagic acid derivatives, hydroxycinnamic acids and anthocyanins with significant increases of 33\%, 22\% and 39\%, respectively. This pest had a significant influence on the plant's secondary metabolism, which improved our understanding of how a strawberry plant reacts to the attacks of this very fast-spreading pest. We have shown that $H$. halys significantly influenced the plant's secondary metabolism. Our study demonstrates how important it is to keep a close watch on the brown marmorated stink bug population and to follow the pest control protocols diligently and responsibly, since H. halys-infested fruit are not suitable for commercial production due to the production of off-flavors, which make the fruit inedible.

Supplementary Materials: The following are available online at https:/ /www.mdpi.com/article/10 $.3390 /$ horticulturae7120561/s1, Figure S1: Chromatograph of phenolics at $530 \mathrm{~nm}$ wavelength, Figure S2: Chromatograph of phenolics at $350 \mathrm{~nm}$ wavelength, Figure S3: Chromatograph of phenolics at $280 \mathrm{~nm}$ wavelength, Table S1: Indiviudal phenolics identification at $530 \mathrm{~nm}$, Table S2: Indiviudal phenolics identification at $350 \mathrm{~nm}$, Table S3: Indiviudal phenolics identification at $280 \mathrm{~nm}$.

Author Contributions: Conceptualization, N.C.W., J.R. and F.Š.; methodology, A.S., T.Z. and J.J.; software, T.Z.; validation, M.H. and R.V.; formal analysis, T.Z.; investigation, N.C.W. and J.R.; resources, M.H. and R.V.; data curation, T.Z.; writing_original draft preparation, T.Z.; writingreview and editing, V.S.; visualization, T.Z.; supervision, A.S., F.Š., M.H., R.V., N.C.W. and J.R.; project administration, M.H., N.C.W. and J.R.; funding acquisition, M.H., R.V., N.C.W. and J.R. All authors have read and agreed to the published version of the manuscript.

Funding: This research was funded by the research and innovation program under grant agreement No. 817946-EXCALIBUR and the Slovenian Research Agency (grants P4-0133 and P4-0072) and the Horticulture P4-0013-0481 program also supported by the Slovenian Research Agency. The APC was funded by the Horticulture P4-0013-0481 program.

Institutional Review Board Statement: Not applicable.

Informed Consent Statement: Not applicable.

Data Availability Statement: The data presented in this study are available on request from the corresponding author. The data are not publicly available due to privacy.

Conflicts of Interest: The authors declare no conflict of interest. 


\section{References}

1. Rot, M. First Record of Brown Marmorated Stink Bug (Halyomorpha halys (Stål, 1855)) (Hemiptera: Pentatomidae) in Slovenia. Acta Entomol. Slov. 2018, 26, 5-12.

2. Schumm, Z.R.; Alston, D.G.; Spears, L.R.; Manlove, K. Impact of Brown Marmorated Stink Bug (Hemiptera: Pentatomidae) Feeding on Tart Cherry (Rosales: Rosaceae) Quality and Yield in Utah. J. Econ. Entomol. 2020, 113, 2328-2334. [CrossRef] [PubMed]

3. Bariselli, M.; Bugiani, R.; Maistrello, L. Distribution and damage caused by Halyomorpha halys in Italy. EPPO Bull. 2016, 46, 332-334. [CrossRef]

4. Hoebeke, E.R.; Carter, M.E. Halyomorpha halys (Stal) (Heteroptera: Pentatomidae): A polyphagous plant pest from Asia newly detected in North America. Proc. Entomol. Soc. Wash. 2003, 105, 225-237.

5. Zamljen, T.; Veberic, R.; Hudina, M.; Slatnar, A. The Brown Marmorated Stink Bug (Halyomorpha halys Stål.) Influences Pungent and Non-Pungent Capsicum Cultivars' Pre- and Post-Harvest Quality. Agronomy 2021, 11, 2252. [CrossRef]

6. Wiman, N.G.; Parker, J.E.; Rodriguez-Saona, C.; Walton, V.M. Characterizing Damage of Brown Marmorated Stink Bug (Hemiptera: Pentatomidae) in Blueberries. J. Econ. Entomol. 2015, 108, 1156-1163. [CrossRef] [PubMed]

7. Aaby, K.; Mazur, S.; Nes, A.; Skrede, G. Phenolic compounds in strawberry (Fragaria x ananassa Duch.) fruits: Composition in 27 cultivars and changes during ripening. Food Chem. 2012, 132, 86-97. [CrossRef] [PubMed]

8. Cesari, M.; Maistrello, L.; Ganzerli, F.; Dioli, P.; Rebecchi, L.; Guidetti, R. A pest alien invasion in progress: Potential pathways of origin of the brown marmorated stink bug Halyomorpha halys populations in Italy. J. Pest Sci. 2015, 88, 1-7. [CrossRef]

9. Medal, J.; Smith, T.; Cruz, A.S. Biology of the Brown Marmorated Stink Bug Halyomorpha halys (Heteroptera: Pentatomidae) in the Laboratory. J. Fla. Entomol. 2013, 96, 1209-1212. [CrossRef]

10. Lee, D.-H.; Wright, S.E.; Leskey, T.C. Impact of Insecticide Residue Exposure on the Invasive Pest, Halyomorpha halys (Hemiptera: Pentatomidae): Analysis of Adult Mobility. J. Econ. Entomol. 2013, 106, 150-158. [CrossRef]

11. Wermelinger, B.; Wyniger, D.; Forster, B. First records of an invasive bug in Europe: Halyomorpha halys Stal (Heteroptera: Pentatomidae), a new pest on woody ornamentals and fruit trees? Mitt.-Schweiz. Entomol. Ges. 2007, 81, 1.

12. Zhou, Y.; Giusti, M.M.; Parker, J.; Salamanca, J.; Rodriguez-Saona, C. Frugivory by Brown Marmorated Stink Bug (Hemiptera: Pentatomidae) Alters Blueberry Fruit Chemistry and Preference by Conspecifics. Environ. Entomol. 2016, 45, 1227-1234. [CrossRef] [PubMed]

13. Weber, N.; Veberic, R.; Mikulic-Petkovsek, M.; Stampar, F.; Koron, D.; Munda, A.; Jakopic, J. Metabolite accumulation in strawberry (Fragaria $\times$ ananassa Duch.) fruits and runners in response to Colletotrichum nymphaeae infection. Physiol. Mol. Plant Pathol. 2015, 92, 119-129. [CrossRef]

14. War, A.R.; Paulraj, M.G.; Ahmad, T.; Buhroo, A.A.; Hussain, B.; Ignacimuthu, S.; Sharma, H.C. Mechanisms of plant defense against insect herbivores. Plant Signal. Behav. 2012, 7, 1306-1320. [CrossRef] [PubMed]

15. Kaur, H.; Salh, P.K.; Singh, B. Role of defense enzymes and phenolics in resistance of wheat crop (Triticum aestivum L.) towards aphid complex. J. Plant Interact. 2017, 12, 304-311. [CrossRef]

16. Short, B.; Khrimian, A.; Leskey, T. Pheromone-based decision support tools for management of Halyomorpha halys in apple orchards: Development of a trap-based treatment threshold. J. Pest Sci. 2017, 90, 1191-1204. [CrossRef]

17. Zamljen, T.; Zupanc, V.; Slatnar, A. Influence of irrigation on yield and primary and secondary metabolites in two chilies species, Capsicum annuum L. and Capsicum chinense Jacq. Agric. Water Manag. 2020, 234, 106104. [CrossRef]

18. Weber, N.; Zupanc, V.; Jakopic, J.; Veberic, R.; Mikulic-Petkovsek, M.; Stampar, F. Influence of deficit irrigation on strawberry (Fragaria $\times$ ananassa Duch.) fruit quality. J. Sci. Food Agric. 2017, 97, 849-857. [CrossRef] [PubMed]

19. Medic, A.; Zamljen, T.; Slatnar, A.; Hudina, M.; Veberic, R. Is Juglone the Only Naphthoquinone in Juglans regia L. with Allelopathic Effects? Agriculture 2021, 11, 784. [CrossRef]

20. Medic, A.; Jakopic, J.; Solar, A.; Hudina, M.; Veberic, R. Walnut (J. regia) Agro-Residues as a Rich Source of Phenolic Compounds. Biology 2021, 10, 535. [CrossRef] [PubMed]

21. Enomoto, H.; Takahashi, S.; Takeda, S.; Hatta, H. Distribution of Flavan-3-ol Species in Ripe Strawberry Fruit Revealed by Matrix-Assisted Laser Desorption/Ionization-Mass Spectrometry Imaging. Molecules 2020, 25, 103. [CrossRef] [PubMed]

22. Hassan, W.H.B.; Abdelaziz, S.; Al Yousef, H.M. Chemical Composition and Biological Activities of the Aqueous Fraction of Parkinsonea aculeata L. Growing in Saudi Arabia. Arab. J. Chem. 2019, 12, 377-387. [CrossRef]

23. Kajdzanoska, M.; Gjamovski, V.; Stefova, M. HPLC-DAD-ESI-MSn identification of phenolic compounds in cultivated strawberry from Macedonia. Maced. J. Chem. Chem. Eng. 2010, 29, 181-194. [CrossRef]

24. Ju, W.-T.; Kwon, O.C.; Kim, H.-B.; Sung, G.-B.; Kim, H.-W.; Kim, Y.-S. Qualitative and quantitative analysis of flavonoids from 12 species of Korean mulberry leaves. J. Food Sci. Technol. 2018, 55, 1789-1796. [CrossRef] [PubMed]

25. Mullen, W.; Boitier, A.; Stewart, A.J.; Crozier, A. Flavonoid metabolites in human plasma and urine after the consumption of red onions: Analysis by liquid chromatography with photodiode array and full scan tandem mass spectrometric detection. $J$. Chromatogr. A 2004, 1058, 163-168. [CrossRef]

26. Panighel, A.; De Rosso, M.; Dalla Vedova, A.; Flamini, R. Putative identification of new p-coumaroyl glycoside flavonoids in grape by ultra-high performance liquid chromatography/high-resolution mass spectrometry. Rapid Commun. Mass Spectrom. 2015, 29, 357-366. [CrossRef] [PubMed] 
27. Spínola, V.; Pinto, J.; Castilho, P.C. Identification and quantification of phenolic compounds of selected fruits from Madeira Island by HPLC-DAD-ESI-MSn and screening for their antioxidant activity. Food Chem. 2015, 173, 14-30. [CrossRef]

28. Sagun, S.; Collins, E.; Martin, C.; Nolan, E.J.; Horzempa, J. Alarm Odor Compounds of the Brown Marmorated Stink Bug Exhibit Antibacterial Activity. J. Pharmacogn. Nat. Prod. 2016, 2, 119. [CrossRef] [PubMed]

29. Milivojević, J.; Maksimović, V.; Nikolić, M.; Bogdanović, J.; Maletić, R.; Milatović, D. Chemical and Antioxidant Properties of Cultivated and Wild Fragaria and Rubus Berries. J. Food Qual. 2011, 34, 1-9. [CrossRef]

30. Santos Sánchez, N.; Salas-Coronado, R.; Hernandez-Carlos, B.; Villanueva, C. Shikimic Acid Pathway in Biosynthesis of Phenolic Compounds. In Plant Physiological Aspects of Phenolic Compounds; Intech: London, UK, 2019. [CrossRef]

31. Weber, N.; Schmitzer, V.; Jakopic, J.; Stampar, F. First fruit in season: Seaweed extract and silicon advance organic strawberry (Fragaria $\times$ ananassa Duch.) fruit formation and yield. Sci. Hortic. 2018, 242, 103-109. [CrossRef]

32. Young, J.E.; Zhao, X.; Carey, E.E.; Welti, R.; Yang, S.-S.; Wang, W. Phytochemical phenolics in organically grown vegetables. Mol. Nutr. Food Res. 2005, 49, 1136-1142. [CrossRef] [PubMed]

33. Veluri, R.; Weir, T.; Bais, H.; Stermitz, F.; Vivanco, J. Phytotoxic and Antimicrobial Activities of Catechin Derivatives. J. Agric. Food Chem. 2004, 52, 1077-1082. [CrossRef]

34. Ullah, C.; Unsicker, S.B.; Fellenberg, C.; Constabel, C.P.; Schmidt, A.; Gershenzon, J.; Hammerbacher, A. Flavan-3-ols Are an Effective Chemical Defense against Rust Infection. Plant Physiol. 2017, 175, 1560-1578. [CrossRef] [PubMed]

35. Lev-Yadun, S.; Gould, K.S. Role of Anthocyanins in Plant Defence. In Anthocyanins: Biosynthesis, Functions, and Applications; Winefield, C., Davies, K., Gould, K., Eds.; Springer: New York, NY, USA, 2009; pp. 22-28.

36. Schaefer, H.M.; Rentzsch, M.; Breuer, M. Anthocyanins Reduce Fungal Growth in Fruits. Nat. Prod. Commun. 2008, 3, 1934578X0800300808. [CrossRef]

37. Gantner, M.; Najda, A.; Piesik, D. Effect of phenolic acid content on acceptancof hazel cultivars by filbert aphid. Plant Prot. Sci. 2019, 55, 116-122. [CrossRef] 